\title{
Electrochemical Properties of EDLC Electrodes Prepared by Acid and Heat Treatment of Commercial Activated Carbons
}

\author{
Jingyu Wu ${ }^{1}$, Ikpyo Hong², Sei-Min Park², Seong-Young Lee ${ }^{2}$ and Myung-Soo Kim ${ }^{1, \wedge}$ \\ ${ }^{1}$ Department of Chemical Engineering, Myongji University, Yongin, Gyonggi-do 449-728, Korea \\ ${ }^{2}$ Carbon Materials Lab, RIST, Pohang, 790-600, Korea \\ ‘e-mail: myungkim@mju.ac.kr \\ (Received May 6, 2008; Accepted June 10, 2008)
}

\begin{abstract}
The commercial activated carbons are typically prepared by activation from coconut shell char or coal char containing lots of inorganic impurities. They also have pore structure and pore size distribution depending on nanostructure of precursor materials. In this study, two types of commercial activated carbons were applied for EDLC electrode by removing impurities with acid treatments, and controlling pore size distribution and contents of functional group with heat treatment. The effect of the surface functional groups on electrochemical performance of the activated carbon electrodes was investigated. The initial gravimetric and volumetric capacitance of coconut based activated carbon electrode which was acid treated by $\mathrm{HNO}_{3}$ and then heat treated at $800^{\circ} \mathrm{C}$ were $90 \mathrm{~F} / \mathrm{g}$ and $42 \mathrm{~F} / \mathrm{cc}$ respectively showing $94 \%$ of charge-discharge efficiency. Such a good electrochemical performance can be possibly applied to the medium capacitance of EDLC.
\end{abstract}

Keywords : EDLC electrode, activated carbon, acid treatment, heat treatment, functional group, electrochemical properties

\section{1. 서 론}

전기이중층 커패시터(EDLC, electric double layer capacitor) 는 대용량의 전기에너지를 저장하고 공급하기 위한 장치로서 기존의 정전 커패시터, 세라믹 커패시터, 전해 컨덴서로는 도 달이 불가능한 수십 수천에 이르는 Farad 용량의 전기에너지 를 빠른시간내에 충전 및 방전할 수 있는 장치이다. 전기이중 층 커패시터는 저에너지 밀도 특성의 재래식 커패시터와 저출 력 밀도 특성을 갖는 이차전지의 단점을 보완하여 순간적인 고 출력 충 방전이 가능한 에너지 장치로서 충 방전 속도가 빠르 고 사이클 수명이 반영구적인 특징을 갖고 있어 이차전지의 병 용 및 대체 가능한 에너지 저장 장치로 각광을 받고 있다[1-4].

전기이중층 커패시터의 전극물질로 탄소재료가 보편적으로 사용되는데 이는 높은 전기 전도성, 내화학성 및 내부식성, 낮 은 열팽창계수 그리고 높은 순도 때문이다. 일반적으로 전기 이중층 커패시터 전극용 탄소재료는 페놀수지, 핏치 등을 탄 화하여 활성화한 비표면적이 $1000 ~ 3000 \mathrm{~m}^{2} / \mathrm{g}$ 의 활성탄이나 활성탄소섬유가 사용된다. 이러한 활성탄소는 다량의 알칼리 계 화학약품을 사용하는 화학적 활성화법에 의하여 제조되므 로 제조공정이 복잡하며 제조원가가 일반활성탄의 $10 \sim 50$ 배 정 도 소요되어 판매가격도 10 100배 정도에 이르고 있다[5-7]. 중저용량 커패시터의 전극재로서 화학활성화법에 의하여 제조 된 활성탄소를 사용할 경우 전극재 원가가 높으므로 제조원가
가 크게 상승하게 된다. 따라서 상용활성탄 및 전구체를 이용 한 물리적 활성화에 의한 저가격형의 전극재가 개발되기 시작 하고 있으며 이를 전극재로서 채용할 경우 커패시터의 원가를 $20 \%$ 이상 크게 절감할 수 있을 것으로 기대된다[8].

전기이중층 커패시터의 성능과 전극용 탄소재료의 비표면적, 총기공부피, 기공크기 분포 및 평균 기공직경 등과의 관계는 이미 많은 연구자들에 의해 자세하게 연구된 바 있다. 이러한 비표면적과 충전용량이 비례하지 않는 현상은 활성탄소의 다 양한 제조공정, 즉 전구체의 상이함과 활성화 공정에서 활성 화 온도 및 표면처리 조건 등의 차이 때문이다. 무엇보다 중 요한 요소는 전극의 기공에 전해질 이온이 쉽게 접근이 가능 한 가이며, 따라서 미세기공의 제어를 주목적으로 하여 공정 이 설계되어야 한다[9-12].

탄소의 표면 젖음성 또한 활성탄소를 전극재로 사용한 전기 이중층 커패시터의 성능을 결정하는 중요한 요소이다. 일반적 으로 활성탄소의 표면에는 다양한 형태의 산성 또는 염기성 관 능기가 존재하며, 이러한 관능기의 작용으로 탄소의 친수성, 소 수성이 결정된다. 전기이중층 커패시터의 전해질은 일반적으 로 수용액 또는 유기용매를 사용하며 커패시터의 성능을 향상 시키기 위해서는 전극과 전해질의 접촉이 원활하게 일어나야 한다. 일반적으로 고온에서 제조되는 탄소의 경우 표면에 친 수성을 나타내는 산소 원자나 산소 관능기 $(-\mathrm{COOH},-\mathrm{COH}$, $\mathrm{C}=\mathrm{O}$ 등)가 남아 있지 않아 소수성을 나타낸다. 이러한 경우 
전해질이 유기용매일 경우 높은 접촉능력을 보이나 수용액을 전해질로 사용하는 경우에는 전극과 전해질의 접촉불량으로 커패시터의 성능이 크게 감소되는 경우가 발생되며, 이를 방 지하고자 다양한 건식 및 습식 표면처리가 연구 또는 수행되 고 있다[13-15]. 탄소재료의 물리화학적 특성 외에도 전극 제 조의 기술적 측면, 즉 결합재의 종류 및 함량, 전극 구성방법 등의 전극의 구성적 측면 또한 최종 제작된 커패시터의 축전 용량을 결정하는 중요 요소이다. 탄소전극의 전기 전도도는 최 종 제작된 커패시터의 성능을 결정하는 핵심 요소이기 때문에 전극에 사용되는 결합재의 함량은 $5 \sim 10 \%$ 이내로 최소화해야 한다[16].

본 연구에서는 coconut shell 계 활성탄과 coal char 계 활성 탄을 화학적 처리에 의하여 불순물 성분을 제거하고, 열처리에 의하여 관능기를 제어한 후 전기이중층 커패시터의 전극재로 사용하여 그 전기화학적 특성에 대하여 조사하였다. 질소등온 흡착에 의하여 비표면적과 세공특성을 분석하였고, Boehm법 에 의하여 전극재의 표면 산성관능기의 종류와 양을 측정하여 전극재의 물리화학적 특성과의 상관관계를 조사하였다.

\section{2. 실험방법}

\section{1. 실험재료}

비표면적이 $1170 \mathrm{~m}^{2} / \mathrm{g}$ 인 coconut shell계 활성탄과 $1077 \mathrm{~m}^{2} / \mathrm{g}$ 인 coal char 계 활성탄(Samchully Carbotech Co.)을 원료로 다 양한 물리 화학적 처리를 하여 전기이중층 커패시터의 전극물 질로 사용하였다. 전극의 조립을 위해 바인더 물질로 $\mathrm{CMC}$ (carboxylmethycellulose sodium salt)와 PTFE (polytetrafluroethylene, $60 \%$ dispersion in water. Aldrich), 용매로는 증류수 를 사용하였으며 분리막은 $\mathrm{PP}($ poly propylene), 전해질은 $1 \mathrm{M}$ TEABF4(tetraethylammonium tetrafluoroborate) 염이 용해된 PC (polycarbonate)전해액을 사용하였다. 원료의 산 처리를 위 하여 질산(Daejung Chem. \& Metals Co., Ltd. 순도 97\%), 염 산(Matsuneon Chem. Ltd., 순도 $35 \%$ ), 황산(Samchun pure chem. Co., Ltd. 순도 $97 \%)$, 왕수 $\left(\mathrm{HCl}: \mathrm{HNO}_{3}\right.$ 의 부피비율 3:1) 를 사용하였다. 활성탄의 산성 표면관능기의 양을 측정하기 위 하여 $\mathrm{NaOH}$ (Shinyo Pure Chem. Co., Ltd.), $\mathrm{NaHCO}_{3}$ (Seoul Chem. Industry. Co., Ltd), $\mathrm{Na}_{2} \mathrm{CO}_{3}$ (Wako Pure Chem. Industries Ltd.)을 titrant로 사용하였으며 $0.1 \mathrm{~N} \mathrm{HCl}$ 표준용액(Daejung Chem. \& Metals Co., Ltd)를 back-titrant로 사용하였다.

\section{2. 활성탄의 후처리}

원료의 불순물을 제거하기 위하여 질산, 염산, 황산 및 왕수 등 산 용액의 원액을 이용하여 coconut shell 계 및 coal char 계 활성탄을 산 처리하였다. $20 \mathrm{~g}$ 의 활성탄에 $200 \mathrm{ml}$ 의 산 용 액을 가하고 $60^{\circ} \mathrm{C}$ 에서 2 시간 동안 충분히 교반시키면서 반응
시켰다. 산 처리가 완료된 활성탄을 산이 완전히 제거될 때까 지 증류수로 충분히 반복하여 세척한 후 $150^{\circ} \mathrm{C}$ 오븐에서 24 시간 동안 충분히 건조시켰다. 산 처리된 활성탄의 표면 관능 기를 제어하기 위하여 질산 처리가 완료된 활성탄을 각각 질 소분위기에서 승온 온도 $10^{\circ} \mathrm{C} / \mathrm{min}$ 로 $500 \sim 1000^{\circ} \mathrm{C}$ 까지 승온한 후 1 시간 동안 열처리 하였다. Micromeritics사의 ASAP 2020 model의 등온흡착 실험장치를 사용하여 산 처리와 열처리에 의한 활성탄의 비표면적과 세공특성에 대한 변화를 관찰하였 으며, Boehm 방법에 의하여 열처리 온도에 따른 전극재의 표 면 산성관능기의 양과 종류를 측정하였다.

\section{3. 제조된 전극재의 전기화학적 특성 펑가}

산 처리와 열처리한 활성탄을 jet-mill을 이용하여 분쇄하고, 도전재로 carbon black, 결합제로 $\mathrm{CMC} / \mathrm{PTFE}$ 를 물에 분산시 켜 planetary mill로 혼합한 후, aluminum foil에 코팅하고 압 착한 뒤 진공 건조기에서 $150^{\circ} \mathrm{C}$ 에서 24 시간 동안 건조하여 전 극재로 사용하였다. 건조 된 전극을 사용하여 glove box 안에 서 coin cell을 제작하였으며 제작된 cell은 $23^{\circ} \mathrm{C}$ 를 유지하면서 cut-off 전압을 $0.1 \sim 2.5 \mathrm{~V}$ 로 하고 처음 5 사이클은 C-Rate를 $2 \mathrm{C}$ 6 번째 사이클부터는 $0.5 \mathrm{C}$ 로 하여 $\mathrm{CC}-\mathrm{CV}$ 충-방전 실험을 수 행하였다. 또한 전극내부의 전기화학 반응을 관찰하기 위하여 IM6(Zahner, Germany)를 사용하여 scan rate를 $50 \mathrm{mV} / \mathrm{s}$ 로 하 여 $0 \sim 2.5 \mathrm{~V}$ 사이를 순환하면서 10 사이클까지 충·방전하면서 전류변화를 관찰하였다.

\section{3. 실험 결과 및 고찰}

\section{1. 원료 활성탄의 전극재로서의 특성}

Coconut shell 계 활성탄과 coal char 계 활성탄을 jet-mill로

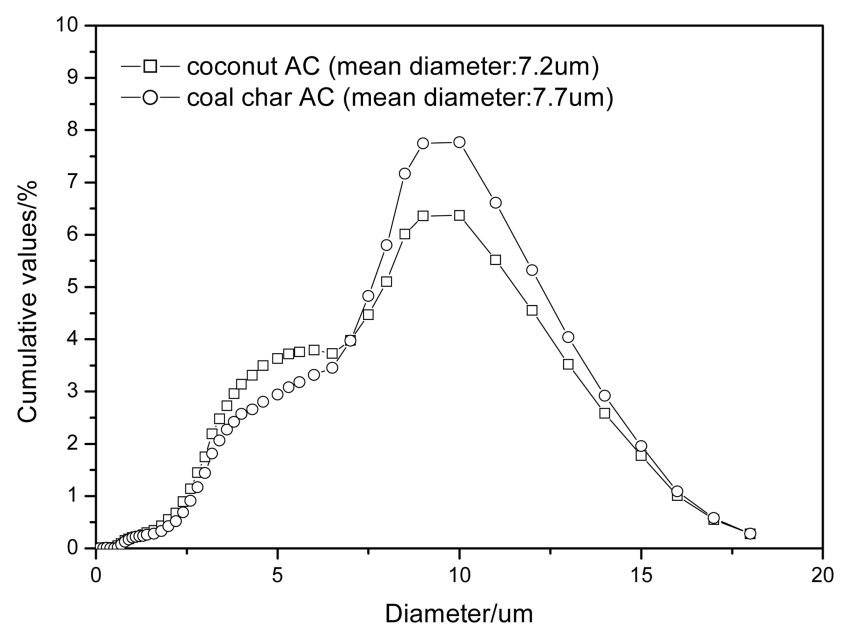

Fig. 1. Particle size distribution of coconut shell based AC and coal char based AC. 
분쇄하여 전극물질로 사용하여 전기화학 특성을 평가하였다. Jet-mill로 분쇄 후 입도 분포를 Fig. 1에 나타내었다. 분쇄 후 대부분의 입자는 $10 \mu \mathrm{m}$ 이하에 주로 분포하였고, 평균 입자크 기는 coconut shell 계 활성탄은 $7.2 \mu \mathrm{m}$, coal char계 활성탄은 $7.7 \mu \mathrm{m}$ 정도를 나타내었으며 전기이중층 커패시터의 전극재로 사용하는데 적절한 크기분포를 가지는 것을 확인할 수 있었다.

Fig. 2은 사이클 진행에 따른 활성탄 전극의 방전용량을 나 타낸 그래프이다. Coconut shell 계 활성탄과 coal char 계 활 성탄을 전극 물질로 사용하였을 때, 초기 무게용량은 각각 66 과 $70 \mathrm{~F} / \mathrm{g}$ 이었고, 초기 부피용량은 39 와 $36 \mathrm{~F} / \mathrm{cc}$ 였다. 그러나 100 사이클 충 - 방전을 반복한 후, 무게용량은 54 와 $66 \mathrm{~F} / \mathrm{g}$ 으 로 감소하였으며 부피용량은 32 와 $34 \mathrm{~F} / \mathrm{cc}$ 로 감소하여 무게용 량 및 부피용량 기준 82 와 $94 \%$ 의 충방전효율을 나타내었다.

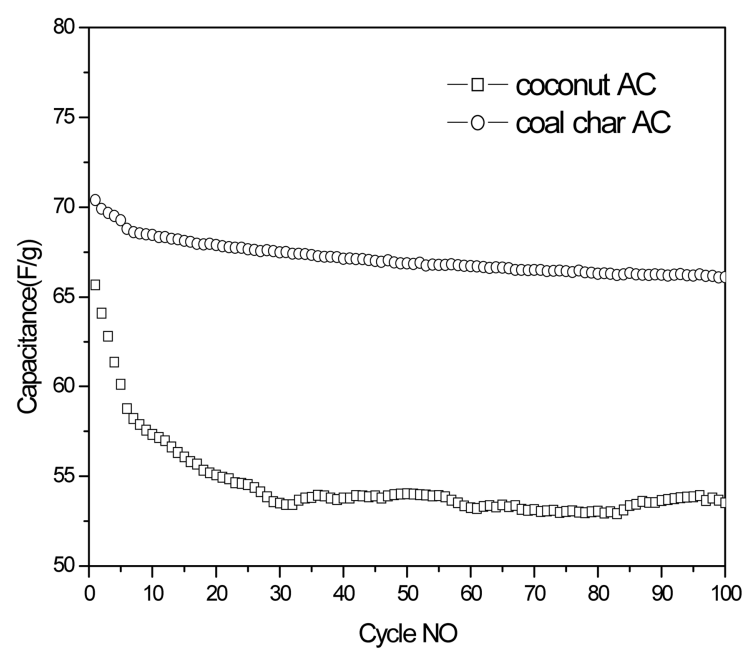

(A) Gravimetric capacitance

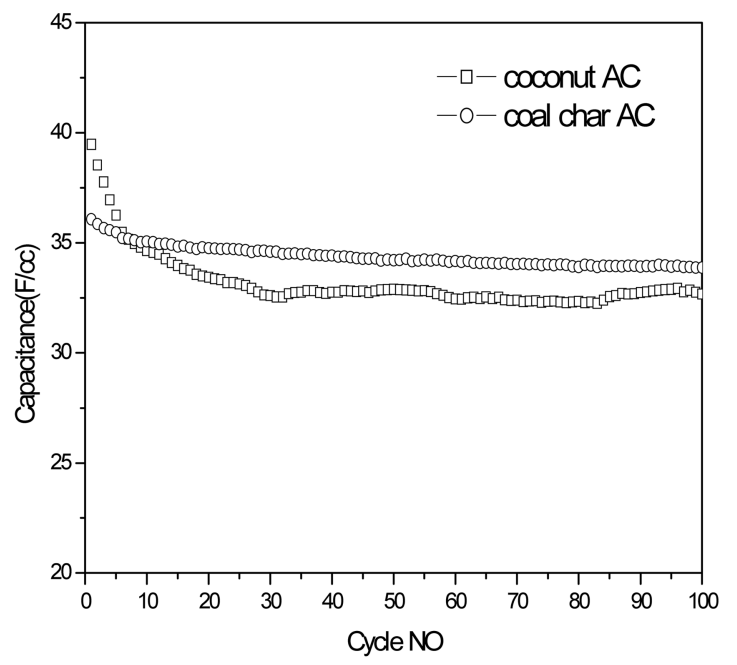

(B) Volumetric Capacitance

Fig. 2. Specific capacitance of coconut based AC and coal char based AC with different acid treatments.
부피용량의 경우 무게용량, 기공 특성, 전극밀도 등에 대한 복 합적인 결과에 의하여 결정되게 되는데, 커패시터를 제조하는 데 있어서 가장 핵심적인 고려사항인 커패시터의 크기에 직접 적인 영향을 주게 되므로 실용화를 위한 중요한 평가지표로서 무게용량과 함께 평가하여 그 결과를 참고적으로 고려하였다. Coconut shell 계 활성탄 원료가 coal char shell 계 활성탄 원 료에 비하여 사이클 안정성이 급격히 하락하는데 이는 coconut shell 계 활성탄의 불순물 함량이 coal char 계 활성탄에 비하 여 높기 때문인 것으로 추측된다. Table 1 에 원료로 사용한 coconut shell 계 활성탄과 coal char 계 활성탄의 ICP (Inductively Coupled Plasma)에 의한 탄소 이외의 미량성분 함량을 분석한 결과를 나타내었다. Coconut shell 계 활성탄에는 칼륨, 나트륨, 알루미늄등과 같은 금속 불순물들이 많이 존재하고 있 어 충·방전 과정에 이와 같은 불순물의 작용에 의하여 전해질 을 분해시켜 각종 화학적 부반응이 일어나게 되므로 비가역용 량이 증가되고, coal char 계 활성탄은 불순물을 상대적으로 적 게 함유하고 있으므로 충·방전 반복에 따른 용량의 저하가 적 은 것으로 판단되었다.

Fig. 3는 coconut shell 계 활성탄과 coal char 계 활성탄 원

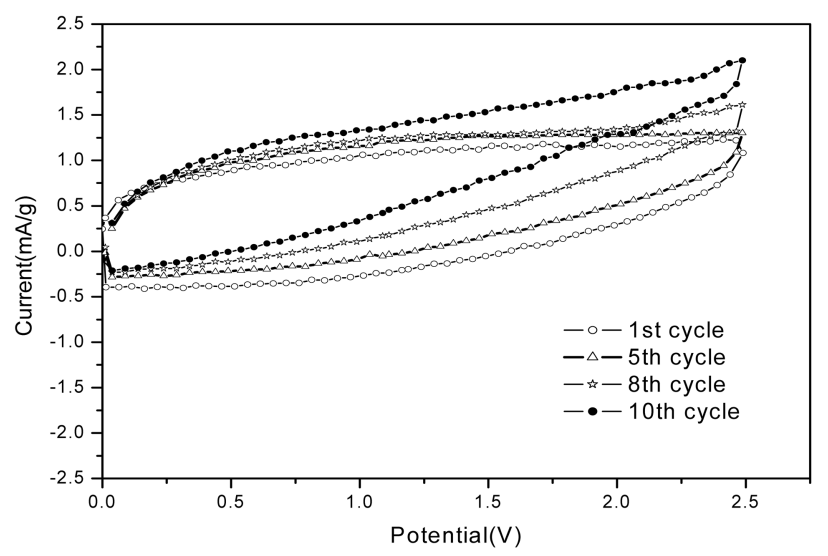

(A)

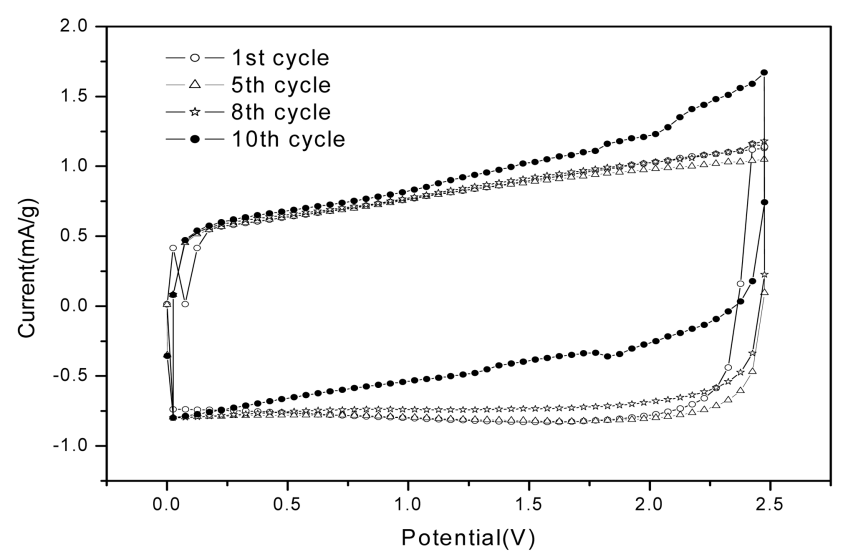

(B)

Fig. 3. Cyclic voltammograms of coconut shell based AC (A) and coal char based AC (B). Scan rate: $50 \mathrm{mV} / \mathrm{s}$ 
Table 1. Ash contents of coconut shell based AC and coal char based AC

\begin{tabular}{lcccccccccc}
\hline & $\mathrm{Al}$ & $\mathrm{Na}$ & $\mathrm{Mg}$ & $\mathrm{Si}$ & $\mathrm{P}$ & $\mathrm{K}$ & $\mathrm{Ca}$ & $\mathrm{Fe}$ & Total \\
\hline Coconut $\mathrm{AC}$ & 16 & 25 & 10 & 5 & 7 & 229 & 12 & 3 & 307 \\
\hline Coal char & 19 & 5 & 3 & 4 & 1 & 7 & 26 & 7 & 72 \\
\hline
\end{tabular}

료를 전극으로 하였을 때의 CV (cyclic voltammogram) 그래 프를 나타낸 것이다. Coal char 계 활성탄을 전극으로 사용 하 였을 때, 첫 사이클의 $0.2 \mathrm{~V}$ 부근에서 피크를 나타내었는데 이 는 불순물에 의한 전해질의 촉매 분해작용에 의해 coin cell의 내부에 기체가 발생했기 때문인 것으로 생각된다. 10 사이클 경과 후 coconut shell 계 활성탄과 coal char 계 활성탄의 $\mathrm{CV}$ 그래프에서 각각 높은 전위 쪽에서 분극현상이 심해지는데, 이 는 충·방전 사이클 반복 진행과정에 전극 중의 불순물이 전해 액과 반응하면서 전해액을 분해하여 부반응이 일어나기 때문 인 것으로 판단된다. $\mathrm{CV}$ 그래프에서의 곡선의 면적은 사이클 당의 용량을 나타내는데 10 사이클 경과 후 두 가지 활성탄에 서 모두 용량이 감소되었고, coconut shell 계 활성탄의 용량의

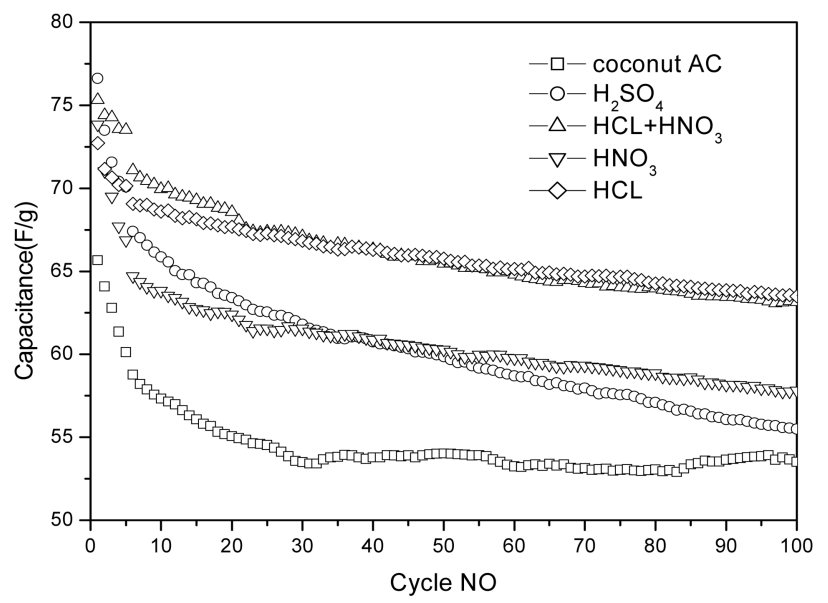

(A)

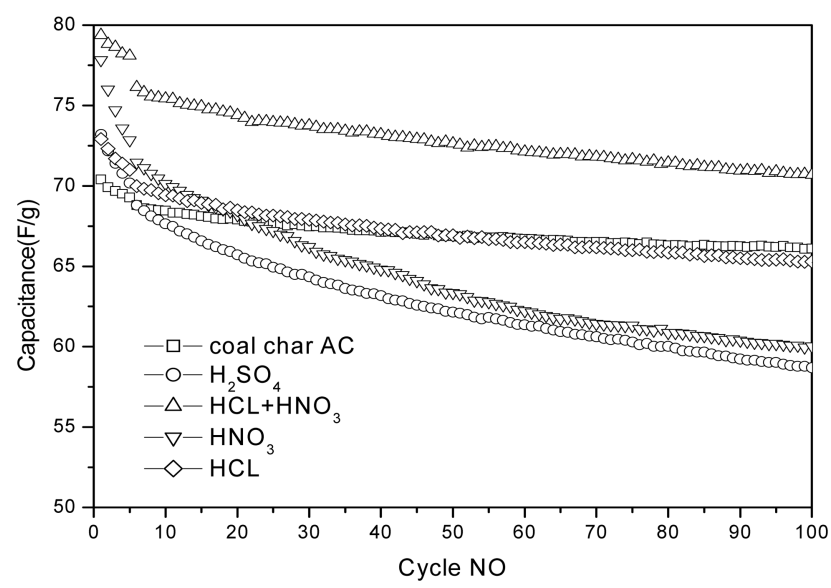

(B)

Fig. 4. Gravimetric capacitance of coconut based AC (A) and coal char based AC (B) with different acid treatments.
감소가 coal char 계 활성탄에 비하여 큰 결과를 나타내었으며 Fig. 2에서 나타낸 결과와 일치하는 결과를 나타내었다.

\section{2. 산 처리에 따른 활성탄의 전극재로서의 특성}

활성탄 원료의 불순물을 제거하여 불순물에 의한 커패시터 의 부 반응을 감소시켜 안정성을 향상시키기 위하여 Coconut shell 계 활성탄과 coal char 계 활성탄을 각각 황산, 왕수, 질 산, 염산으로 산 처리하였다. 산 처리된 활성탄을 커패시터의 전극물질로 사용하였을 때 처리하지 않은 원료와 비교하여 사 이클 진행에 따른 무게 방전용량과 부피 방전용량을 Fig. 4와 Fig. 5 에서 나타내었다. 산 처리한 활성탄의 무게 용량은 원료

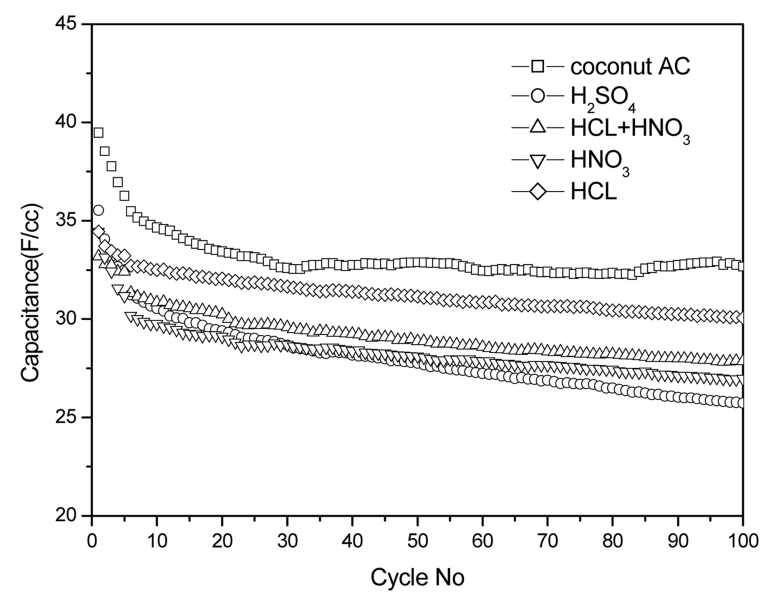

(A)

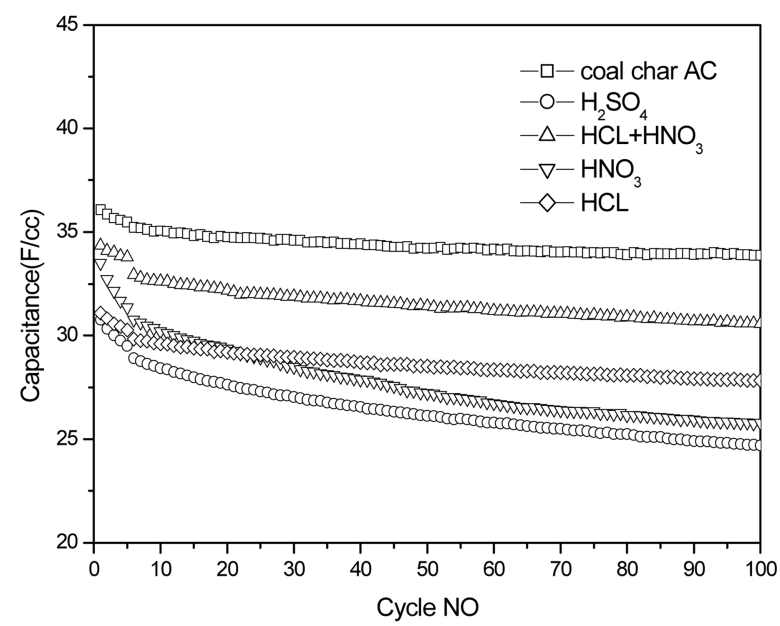

(B)

Fig. 5. Volumetric capacitance of coconut based AC (A) and coal char based AC (B) with different acid treatments. 
Table 2. Specific surface area of coconut based AC and coal char based AC with different acid treatment

\begin{tabular}{|c|c|c|c|c|c|}
\hline Sample & $\mathrm{SSA}\left(\mathrm{m}^{2} / \mathrm{g}\right)$ & $\mathrm{S}_{\mathrm{mi}}\left(\mathrm{m}^{2} / \mathrm{g}\right)$ & $\mathrm{S}_{\mathrm{mi}} / \mathrm{SSA}(\%)$ & $\mathrm{S}_{\mathrm{ext}}\left(\mathrm{m}^{2} / \mathrm{g}\right)$ & $\mathrm{S}_{\mathrm{ext}} / \mathrm{SSA}(\%)$ \\
\hline Coconut AC & 1170 & 1087 & 92.9 & 83 & 7.1 \\
\hline $\mathrm{H}_{2} \mathrm{SO}_{4}$ & 1189 & 1115 & 93.8 & 74 & 6.2 \\
\hline $\mathrm{HCl}+\mathrm{HNO}_{3}$ & 1203 & 1115 & 92.7 & 88 & 7.3 \\
\hline $\mathrm{HNO}_{3}$ & 1331 & 1236 & 92.9 & 95 & 7.1 \\
\hline $\mathrm{HCl}$ & 1178 & 1104 & 93.7 & 74 & 6.3 \\
\hline Coal char AC & 1077 & 884 & 82.1 & 193 & 17.9 \\
\hline $\mathrm{H}_{2} \mathrm{SO}_{4}$ & 1443 & 1180 & 81.8 & 263 & 18.2 \\
\hline $\mathrm{HCl}+\mathrm{HNO}_{3}$ & 1111 & 931 & 83.8 & 180 & 16.2 \\
\hline $\mathrm{HNO}_{3}$ & 1184 & 964 & 81.4 & 220 & 18.6 \\
\hline $\mathrm{HCl}$ & 1253 & 798 & 63.7 & 455 & 36.3 \\
\hline
\end{tabular}

SSA: BET surface area; $\mathrm{S}_{\mathrm{mi}}$ : micropore area; $\mathrm{S}_{\mathrm{ext}}$ : external surface area

에 비해 좋은 결과를 나타내었고, 그 중에서 왕수 처리를 한 활성탄을 전극 물질로 사용했을 때 가장 높은 방전용량을 나 타냈다. 왕수 처리를 한 활성탄을 전극 물질로 사용했을 때 coconut shell 계 활성탄과 coal char 계 활성탄의 초기 무게용 량은 각각 75 와 $79 \mathrm{~F} / \mathrm{g}$ 을 나타냈으며 100 사이클 후 용량은 63 과 $71 \mathrm{~F} / \mathrm{g}$ 을 나타내었다. 질산 및 황산 처리된 활성탄을 전 극 물질로 사용하였을 때 초기 용량은 왕수 처리된 활성탄과 비슷하지만 사이클 안정성이 급격히 하강되었다. 이는 질산 및 황산 처리 후 활성탄의 표면에 친수성을 띤 산성 관능기가 상 대적으로 비교적 많이 생성되는데 이러한 산성 관능기는 수용 액을 전해질로 사용하는 경우에는 전극과 전해질의 접촉을 원 활하게 해 주지만 유기용매 전해질 중에서는 전극과 전해질의 접촉을 방해하기 때문에 용량이 감소되게 된다[25]. 산 처리된 활성탄의 무게 용량이 증가된 것은 산 처리 과정을 통하여 불 순물이 제거되어 원래의 불순물 자리에 새로운 기공이 증가되 어 비표면적이 다소 증가되었고, 활성탄 제조과정에서 충분히 탄소화되지 않고 일부 저분자량의 휘발성분으로 존재하고 있 던 부분이 산에 의하여 분해되어 새로운 세공을 일부 형성하 기 때문인 것으로 판단된다. Table 2 는 산 처리에 따른 활성탄 시료의 비표면적의 측정 결과이다. 산 처리된 활성탄은 무게 용량은 증가하였으나 부피 용량은 원료에 비해 낮은 결과를 나타내었다.

\section{3. 질산처리 및 열처리한 활성탄의 전극재로서의 특성}

산 처리된 활성탄을 커패시터의 전극재로 사용하였을 때 무 게용량은 원료에 비하여 증가되었으나 충·방전 사이클 반복 에 따라 용량의 저하가 크게 발생하는 결과를 나타내었다. 산 처리를 통하여 불순물 제거에도 불구하고 사이클 특성이 저하 되는 것은 산 처리에 의하여 활성탄 표면에 새로운 산성 관능 기가 추가적으로 생성되었기 때문인 것으로 판단된다. 질산 처 리된 활성탄의 방전용량 그래프를 보면 초기용량은 비슷하나 사이클 특성이 급격히 하강하는 것을 볼 수 있었다. 따라서 질 산 처리에 의하여 활성탄의 표면에 형성된 관능기를 확인하고,

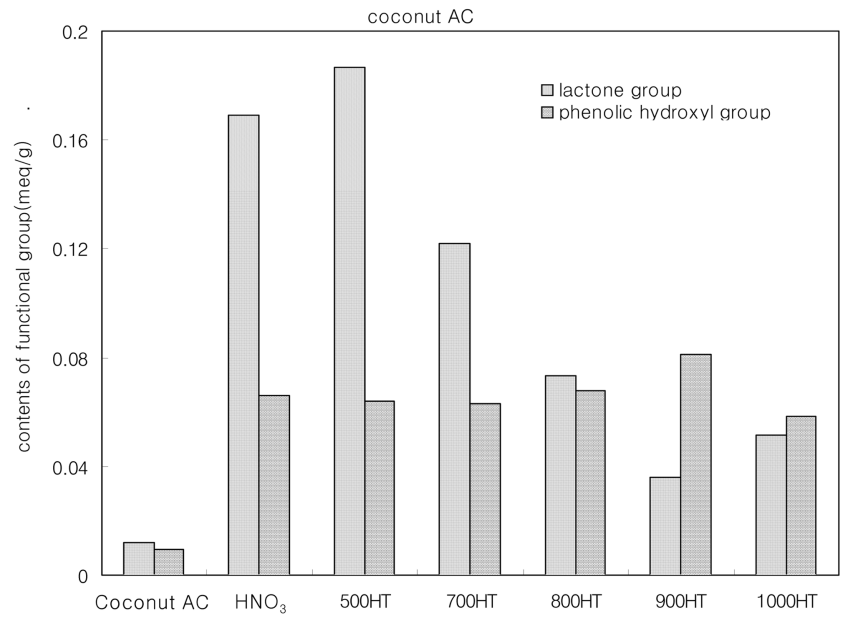

(A)

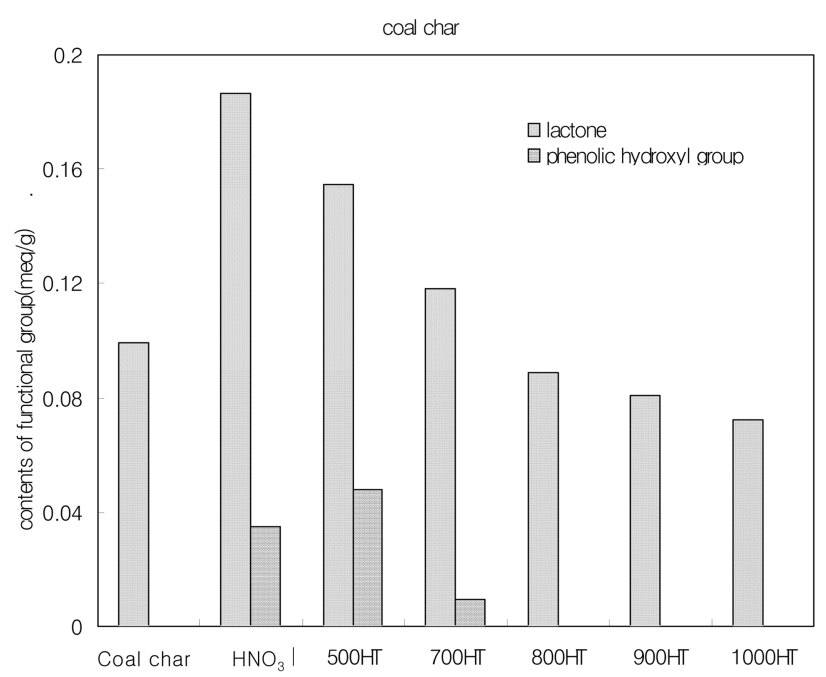

(B)

Fig. 6. Contents of acidic surface functional group of coconut based $\mathrm{AC}(\mathrm{A})$ and coal char based $\mathrm{AC}(\mathrm{B})$ with different heat treatment temperatures after $\mathrm{HNO}_{3}$ treatment. 
이를 열처리에 의해 제거함으로써 전극재의 표면관능기가 커 패시터의 성능에 미치는 영향을 관찰해 보고자 하였다. 활성 탄의 표면관능기 양은 Boehm 법을 이용하여 측정하였으며 실 험결과를 Fig. 6에 나타내었다. Coconut shell 계 활성탄과 coal char 계 활성탄 모두 질산 처리 이후 표면에 lactone group과 phenolic hydroxyl group 산성 관능기가 크게 증가되었다. 열 처리 온도의 증가에 따라 lactone group은 coconut shell 계 활 성탄과 coal char 계 활성탄에서 모두 감소된 결과를 나타내어 열처리에 따라 lactone group이 분해된다는 것을 알 수 있었다. 그러나 phenolic hydroxyl group의 경우, 두 가지 활성탄에서 각각 다른 특성을 나타내었는데, coal char 계의 경우에는 상 대적으로 용이하게 분해가 되는 반면, coconut shell 계의 경우 에는 $1000^{\circ} \mathrm{C}$ 까지의 열처리에도 용이하게 제거되지 않는 결과 를 나타내었다. 이는 원료의 종류에 따른 표면의 결정화도, 미 세조직구조, 구체적인 관능기의 종류와 양 등에 따라 좌우되

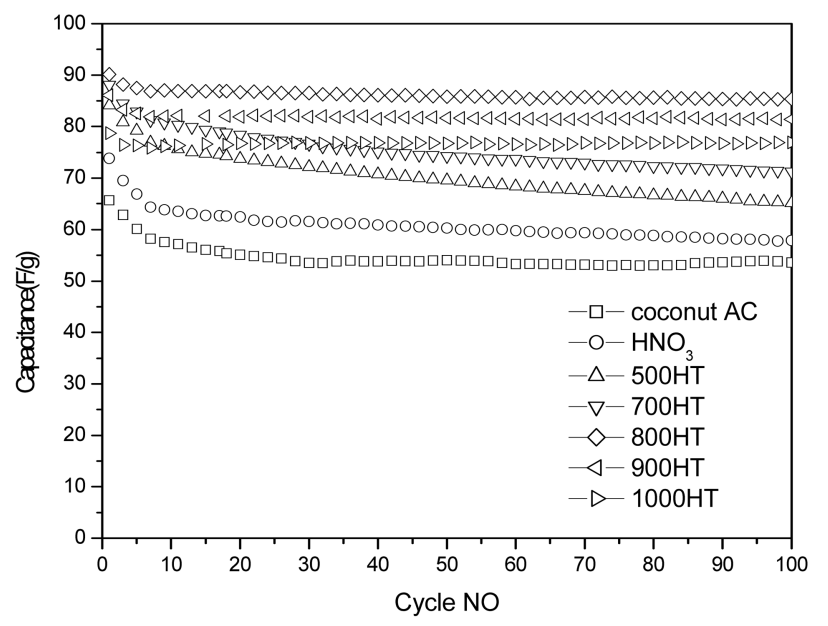

(A)

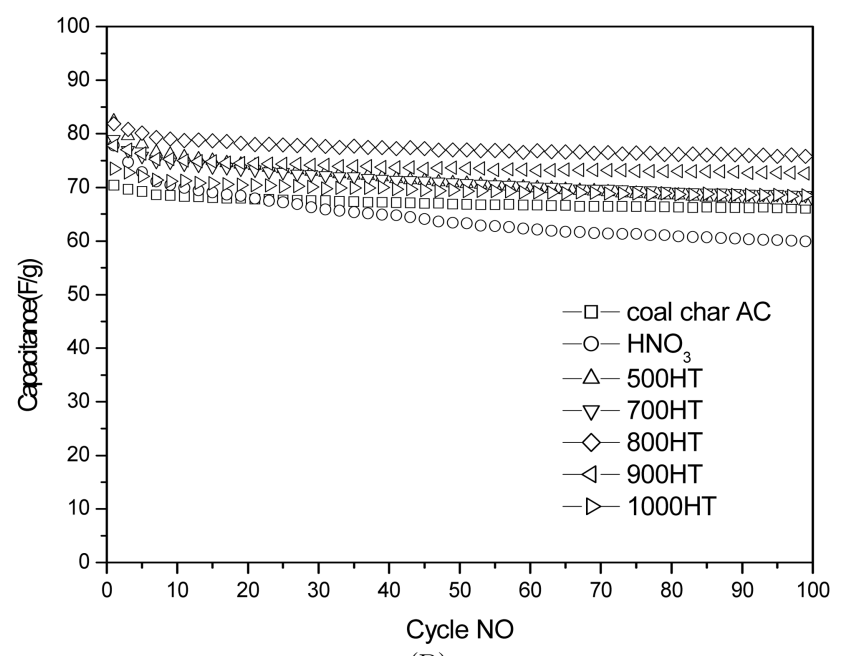

(B)

Fig. 7. Gravimetric capacitance of coconut based AC (A) and coal char based $\mathrm{AC}(\mathrm{B})$ with different heat treatment temperatures after $\mathrm{HNO}_{3}$ treatment.
는 것으로 추측되고, 별도의 상세한 연구를 통한 메커니즘의 규명이 필요하다. 관능기의 총량은 열처리 온도에 따라 감소 하는 경향을 나타내나 $800^{\circ} \mathrm{C}$ 이상에서는 분해되는 양이 현저 히 낮아지는 것을 볼 수 있다.

질산 처리된 활성탄을 여러 가지 온도에서 열처리 하여 전 극재로 사용하였을 때 사이클 진행에 따른 무게방전용량과 부 피 방전용량을 Fig. 7과 8에 나타내었다. 질산 처리된 coconut shell 계 활성탄과 coal char 계 활성탄은 열처리 온도가 상승 함에 따라 방전용량이 모두 증가되었으며 사이클 특성도 우수 하였다. 이 결과를 Fig. 9에 열처리 온도에 따른 초기용량과 100 사이클 충 방전 후의 용량으로 나타내었다. 열처리 온도 가 $800^{\circ} \mathrm{C}$ 일 때 coconut shell 계 활성탄과 coal char 계 활성탄 의 초기 무게용량은 각각 90 과 $82 \mathrm{~F} / \mathrm{g}$ 으로서 가장 높은 용량을 나타내었으며, 100 사이클 후 무게용량이 각각 85 와 $76 \mathrm{~F} / \mathrm{g}$ 로 서 $94 \%$ 와 $93 \%$ 의 충 - 방전 효율을 나타내었다. 그러나 열처

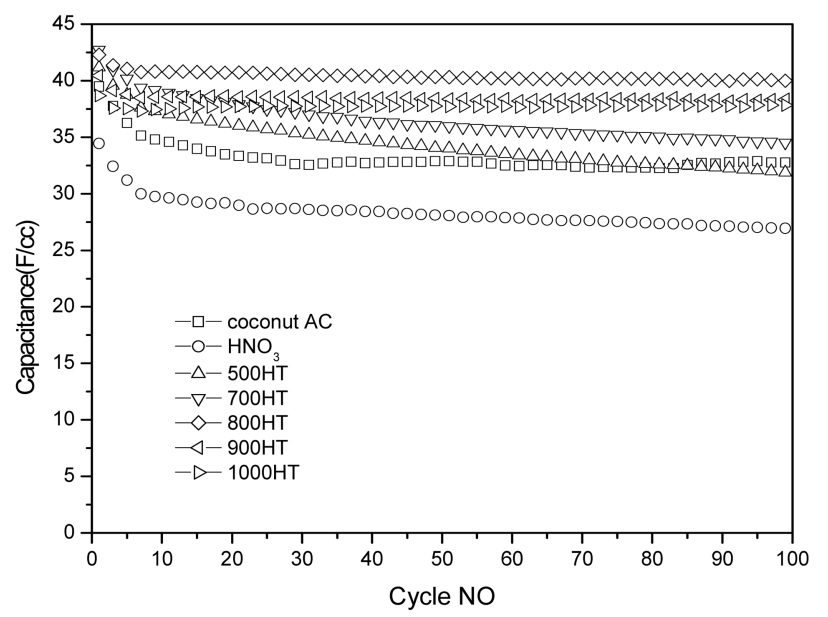

(A)

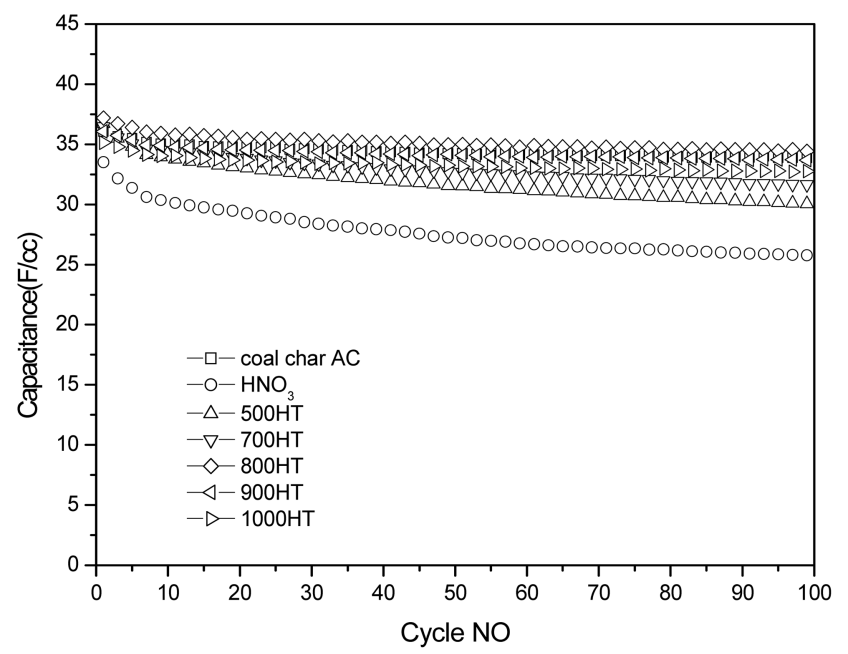

(B)

Fig. 8. Volumetric capacitance of coconut based AC (A) and coal char based AC (B) with different heat treatment temperatures after $\mathrm{HNO}_{3}$ treatment. 


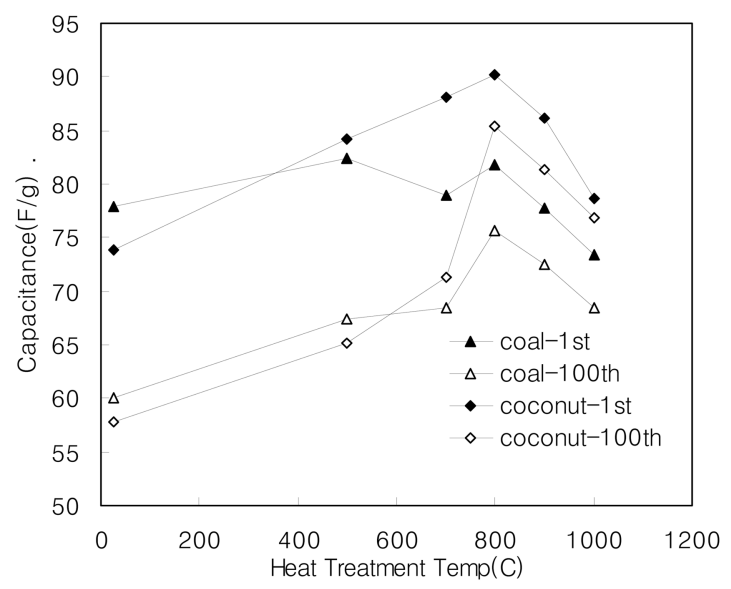

(A)

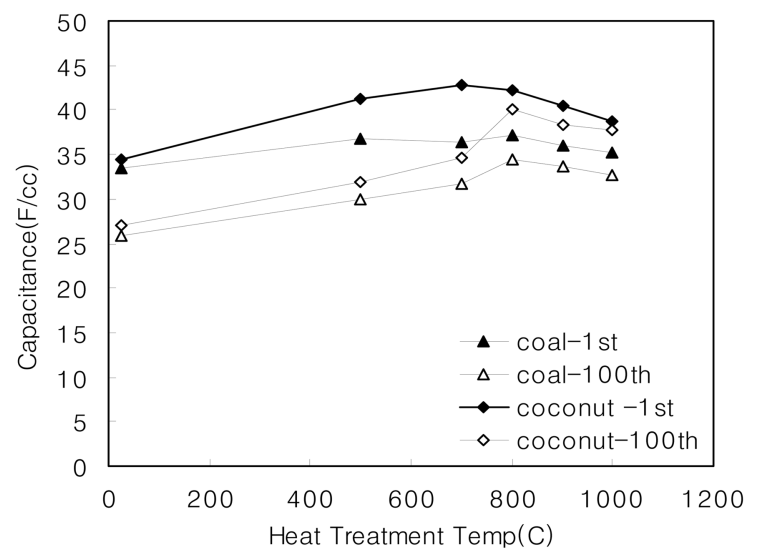

(B)

Fig. 9. Specific capacitance with different heat treatment temperatures.

(A): Gravimetric capacitance, (B): volumetric capacitance
리 온도가 $800^{\circ} \mathrm{C}$ 이상에서는 용량이 감소되는 것을 알 수 있 었다. Coconut shell 계 활성탄과 coal char 계 활성탄의 초기 부피용량도 $800^{\circ} \mathrm{C}$ 에서 각각 42 와 $37 \mathrm{~F} / \mathrm{cc}$ 를 나타내었으며, 100 사이클 후 40 과 $34 \mathrm{~F} / \mathrm{cc}$ 를 나타냄으로 사이클 특성과 방전용 량이 모두 가장 높은 결과를 나타내었다. 용량이 열처리 온도 의 증가에 따라 증가되는 것은 열처리 온도의 증가에 따라 활 성탄 표면의 산성 관능기가 감소하므로 충전시 삽입 가능한 이온의 양이 증가하였기 때문이라고 판단되며, $800^{\circ} \mathrm{C}$ 이상에 서 용량이 감소되는 것은 $800^{\circ} \mathrm{C}$ 이상에서 활성탄 표면의 산 성관능기의 감소양이 미미한 반면 열처리 온도가 높아짐에 따 라 세공구조가 축소되면서 삽입될 수 있는 이온의 양이 감소 하기 때문으로 추측된다.

Table 3은 열처리 온도에 따른 비표면적 측정 결과이다. 원 료에 비하여 산 처리 후, 열처리한 활성탄의 비표면적은 모두 다소 증가하였으나, 열처리 온도에 따라 $900^{\circ} \mathrm{C}$ 이상에서 비표 면적이 조금씩 감소하며 질산처리 활성탄에 비하여 추가로 열 처리한 활성탄이 micropore 표면적이 줄어들고 mesopore와 macropore 표면적이 증가되는 결과를 나타내었다.

\section{4. 결 론}

Coconut shell 계 및 coal char 계 상용 활성탄을 화학적 처 리에 의하여 불순물 성분을 제거하고, 열처리에 의하여 관능 기를 제어하여 전극재를 제조하였다. 제조된 전극재의 전기이 중층 커패시터의 전극재로서의 전기화학적 특성을 조사하고 세공특성 및 전극재 표면의 화학적 특성을 평가하여 다음과 같은 결론을 얻었다.

1. Coconut shell 및 coal char 계 활성탄을 별도의 처리없이 전기이중층 커패시터의 전극재로 사용하였을 때 충-방전 반

Table 3. Specific surface area and porosity parameters of samples

\begin{tabular}{|c|c|c|c|c|c|c|c|}
\hline Sample & $\mathrm{SSA}\left(\mathrm{m}^{2} / \mathrm{g}\right)$ & $\mathrm{S}_{\mathrm{mi}}\left(\mathrm{m}^{2} / \mathrm{g}\right)$ & $\mathrm{S}_{\mathrm{ext}}\left(\mathrm{m}^{2} / \mathrm{g}\right)$ & $\mathrm{V}_{\text {tot }}\left(\mathrm{cm}^{3} / \mathrm{g}\right)$ & $\mathrm{V}_{\mathrm{mi}}\left(\mathrm{cm}^{3} / \mathrm{g}\right)$ & $\mathrm{V}_{\mathrm{mi}} / \mathrm{V}_{\text {tot }}(\%)$ & $\mathrm{D} / \mathrm{nm}$ \\
\hline Coconut & 1170 & 1087 & 83 & 0.471 & 0.427 & 91 & 1.61 \\
\hline $\mathrm{HNO}_{3}$ & 1331 & 1236 & 95 & 0.537 & 0.488 & 91 & 1.61 \\
\hline $500^{\circ} \mathrm{C}$ & 1225 & 1103 & 121 & 0.497 & 0.436 & 88 & 1.62 \\
\hline $700^{\circ} \mathrm{C}$ & 1245 & 1118 & 127 & 0.506 & 0.442 & 87 & 1.63 \\
\hline $800^{\circ} \mathrm{C}$ & 1258 & 1132 & 126 & 0.511 & 0.447 & 87 & 1.62 \\
\hline $900^{\circ} \mathrm{C}$ & 1257 & 1137 & 120 & 0.509 & 0.448 & 88 & 1.62 \\
\hline $1000^{\circ} \mathrm{C}$ & 1253 & 1129 & 124 & 0.509 & 0.446 & 88 & 1.63 \\
\hline Coal & 1077 & 884 & 193 & 0.463 & 0.363 & 78 & 1.72 \\
\hline $\mathrm{HNO}_{3}$ & 1184 & 964 & 220 & 0.509 & 0.396 & 78 & 1.72 \\
\hline $500^{\circ} \mathrm{C}$ & 1188 & 925 & 264 & 0.508 & 0.374 & 74 & 1.71 \\
\hline $700^{\circ} \mathrm{C}$ & 1234 & 956 & 278 & 0.529 & 0.387 & 73 & 1.71 \\
\hline $800^{\circ} \mathrm{C}$ & 1209 & 943 & 266 & 0.517 & 0.382 & 74 & 1.71 \\
\hline $900^{\circ} \mathrm{C}$ & 1218 & 947 & 271 & 0.521 & 0.384 & 74 & 1.71 \\
\hline $1000^{\circ} \mathrm{C}$ & 1118 & 862 & 256 & 0.480 & 0.350 & 73 & 1.72 \\
\hline
\end{tabular}

SSA: BET surface area; $\mathrm{S}_{\mathrm{mi}}$ : micropore area $\mathrm{S}_{\mathrm{ext}}$ : external surface area; $\mathrm{V}_{\text {tot }}$ : total volume; $\mathrm{V}_{\mathrm{mi}}$ : micropore volume; $\mathrm{D}$ : average pore diameter 
복에 따른 용량의 감소폭이 크며 $\mathrm{CV}$ 특성도 부반응에 의한 분 극현상이 크게 발생하므로 전극재로서의 사용은 적합하지 않 았다.

2. 활성탄을 산 처리하는 경우 비표면적의 증가에 따라 무 게용량은 증가하였으나, 표면에 산성 관능기가 많이 생성되어 사이클 안정성이 낮아졌다. 추가 열처리에 의하여 관능기의 양 이 감소하나 micropore가 감소하고 mesopore와 macropore가 증가하여 세공분포에 영향을 미치므로 $800^{\circ} \mathrm{C}$ 정도에서 열처 리하는 것이 바람직하였다.

3. 질산 처리 및 열처리에 의하여 불순물, 세공분포 및 표면 관능기를 제어한 활성탄을 전극재로서 사용하는 경우 용량 및 사이클 특성이 크게 향상되어 coconut shell 계 활성탄을 질산 및 $800^{\circ} \mathrm{C}$ 열처리한 전극재는 초기 용량 $90 \mathrm{~F} / \mathrm{g}, 42 \mathrm{~F} / \mathrm{cc}$ 및 100 사이클 후 $85 \mathrm{~F} / \mathrm{g}, 40 \mathrm{~F} / \mathrm{cc}$ 으로 $94 \%$ 의 효율을 나타내어 원료 활 성탄 대비 크게 개선된 부피용량과 사이클 특성을 나타내었다.

\section{참고문헌}

[1] Kwon, O. J.; Jung, Y. H.; Oh, S. M. J. Power sources 2004, $125,221$.

[2] Lee, J.; Kim, J.; Lee, Y.; Yoon, S.; Oh, S. M.; Hyeon, T.
Chem. Mater. 2004, 16, 3323.

[3] Bonnefoi, L.; Simon, P.; Fauvarque, J. F.; Sarrazin, C.; Dugast, A. J. Power Source 1999, 79, 37.

[4] Tanahashi, I.; Yoshida, A.; Nishino, A. Denki Kagaku 1988, 56, 892.

[5] Park, S. J.; Jung, W. Y. J. Colloid Interface Sci. 2002, $250,93$.

[6] Inagaki, M.; Radovic, L.R. Carbon 2002, 40, 2263.

[7] Burke, A. J. Power sources 2000, 91, 37.

[8] Qiao, W. M.; Korai, Y.; Mochida, I.; Hori, Y.; Maeda, I. Carbon 2002, 40,351.

[9] Qu, D. J. Power Source 2002, 109, 403.

[10] Sarangapani, S.; Tilak, B. V.; Chen, C. P. J. Electrochem. Soc. 1996, 143, 3791

[11] An, K. H.; Jeon, K. K.; Heo, J. K.; Lim, S. C.; Bae, D. J.; Lee, Y. H. J. Electrochem. Soc. 2002, 149, 1058.

[12] Lee, K. T.; Jung, Y. S.; Oh, S. M. J. Am. Chem. Soc. 2003 , $125,5652$.

[13] Park, S. J.; Jang, Y. S. J. Colloid Interface Sci. 2002, 249, 458.

[14] Park, S. J.; Seo, M. K.; Rhee, K. Y. Carbon 2003, 41, 592.

[15] Park, S. J.; Seo, M. K.; Rhee, K. Y. J. Phys. Chem. B. 2003, 107, 13100.

[16] Frackowiak, E.; Beguin, F. Carbon 2001, 39, 937. 